\title{
State stabilization macroeconomic policy: features and prospects for Ukraine
}

\author{
Roman Kalinovskyi \\ Department of Economic Theory, Macroeconomics and Microeconomics \\ Taras Shevchenko National University of Kyiv \\ Kyiv, Ukraine \\ e-mail correspondence: roma_kalina@mail.ru
}

\begin{abstract}
The research reveals the essence of the process of state stabilization macroeconomic policy, which includes two main directions: fiscal policy influence on the budget balancing and monetary regulation of economy through the transmission mechanism improvement and monetary regime defining. The key problems connected with the state budget deficit are investigated. The state and dynamics of the Ukraine state budget are considered. The ways of overcoming the consequences of state budget imbalances are analyzed. The concept of transmission mechanism was defined. Were shown and explained all the key channels of monetary transmission used in Ukraine and in the world, and were suggested the ways to improve their efficiency, which in future may lead to the improvement of the economic situation in Ukraine. Was justified the necessity of improving the transmission mechanism for the monetary policy strategic objectives achieving. Were given the recommendations on how to improve the channels of transmission mechanism in Ukraine with the aim of increasing the effectiveness of monetary stabilization policy. The basic monetary regimes implementation in various countries of the world and the resulting consequences are researched. The benefits of inflation targeting regime for the state's monetary policy effectiveness enhancing are justified. Recommendations for further implementation of the inflation targeting regime in Ukraine are provided.
\end{abstract}

Keywords: Stabilization policy, Budget deficit, Transmission mechanism, Transmission channels, Monetary regimes, Inflation

\section{INTRODUCTION}

The current stage of economic development of Ukraine is determined by the impact of the crisis on all aspects of society, hence the need for development and implementation of active measures of regulatory impact in order to minimize the negative impact of the crisis on the national economy. In such circumstances, the research of problems related to optimization of the Central Bank's monetary policy tools of influence on the real sector of the economy are particularly relevant. Despite the fact that Central Bank has no direct influence on the achievement of the ultimate strategic goals of monetary regulation with the help of own instruments, there is a need of the achievement of defined tactical objectives, which is the direct influence of the Central Bank, i.e. involves the use of an appropriate transmission mechanism of monetary regulation. Therefore, a necessary condition for effective influence of monetary policy on the course of economic processes is the construction of effective 
mechanism of monetary transmission that provides transmission of corresponding impulses of monetary regulation on the real sector.

On the other hand, structure and dynamics of the state budget is the main indicator of the financial condition of any state. Permanent deficit of the state budget creates problems associated with the inability of the state to ensure the effective implementation of its functions, as well as loss of confidence of international credit institutions and a further rise in the borrowed funds cost. Today the majority of countries in the world have a deficiency of the state budget, and in Ukraine it has become a chronic problem that determines the relevance of the study.

The issues of formation and maintenance of the stabilization policy of the state, the development of effective programs for the state budget balancing, the use of appropriate stabilization instrumentation are very relevant and widely reported in Ukrainian and world scientific works. Recently, the problem of the budget deficit overcoming and of the effective monetary policy providing has become widespread and is in the research interests of a significant number of scientists. Among the representatives of western and Ukrainian economic thought, which investigated the issue, it should be noted Andrushchak (2011); Arzhevitin (2009); Balastryk (2010); Bazylevych (2007); Danilenko (2010); Demianyshyn (2009); Dzyublyk (2012); Gnativ (2009); Gordienko (2012); Grytsenko (2008); Keynes (1999); Kolisnyk (2011); Koncewicz (2012); Kornev (2015); Mashko (2010); Mishchenko (2010); Papaika (2010); Petlenko (2017); Prushkovskaya (2010); Radionova (2010); Slipchenko (2011); Stelmakh (2009); Stiglitz (1999); Vishnevska (2015) and others.

While there is no single opinion regarding the extent and the urgency of overcoming the state budget deficit, but researchers offered various ways and methods of dealing with this phenomenon. Also there is a tendency to a more thorough analysis of this problem in the aspect of deepening of the global economy debt processes in general and Ukraine in particular.

This study examines, among other things, such unresolved parts of the general problem as the search of ways to increase the efficiency of the state budget balancing and of the transmission channels, as well as the increasing of degree of the Central Bank influence on the economy by changing the existing monetary regime to more optimal.

The purposes of the research are: 1) Investigation of the influence of the state budget deficit for the implementation of the fiscal stabilization policy; 2) Examining of channels of the monetary policy transmission mechanism in Ukraine and searching for the ways to improve them with the purpose of the efficiency increasing of the Central Bank influence on the real sector of economy; 3) Consideration of the basic choices of monetary regime of monetary policy, which include the monetary targeting regime, the regime of exchange rate targeting, the inflation targeting regime, and a strategy without an explicit nominal anchor.

The main objectives of the study are: disclosure of such economic phenomena as the state budget deficit, monetary regimes and channels of the monetary policy transmission mechanism; highlight the key problems associated with the deficit of the state budget; review of the status and dynamics of the Ukraine state budget; finding ways to overcome the unbalance of the state budget and elimination of the consequences of this phenomenon; highlight the key features of each transmission channel; analyze the transmission channels in Ukraine and in the world; finding ways to improve the transmission mechanism in Ukraine for the efficiency increasing of the Central Bank influence on the real sector of economy; justify the benefits of inflation targeting regime for the state's monetary policy effectiveness enhancing; provide 
recommendations for further improvement of the stabilization macroeconomic policy in Ukraine.

The research object is the provision of effective stabilization policy as a means of overcoming the negative processes and phenomena in the economy. The research subject is the analysis of fiscal and monetary policies' instruments to find the ways for the improvement of state stabilization macroeconomic policy in Ukraine. Practical implications. Thoroughly examined the research topic, conclusions were drawn concerning the promising directions of development of fiscal and monetary policy in Ukraine, as well as recommendations on further actions of the state bodies of Ukraine.

\section{METHODS}

The research is based on a comparison of data on the effectiveness of monetary and fiscal policy in different countries in specific time periods. During the investigation were used such scientific methods as abstraction, analysis, structure method and others.

\section{RESULTS AND DISCUSSION}

State budget as an economic category reflects the real economic relations between the state and other economic actors about the accumulation and use of centralized cash resources of the country, is designed to perform the functions of the state by the distribution and redistribution of GDP.

The state budget as the main financial plan of the state is the monetary expression of the income and expenditure of the state for a certain period of time. The formation of the financial resources reflected in the budget revenues and their use - in its costs.

Budget revenues are formed by tax and non-tax and other revenues, which are made on an irrevocable basis, including transfers, gifts, grants, etc. Budget expenditures reflect the funds allocated for the financing of planned public programs and activities, except for funds designated for repayment of the principal amount of the state debt and refund of overpaid to the budget amounts.

Depending on the balance between revenues and expenditures the budget may be balanced or unbalanced, that is to have a deficit or surplus. Budget deficit occurs when the budget revenues do not cover its spending, the budget surplus is when revenues exceed the budget expenses.

Since the government, like everyone, has to pay its bills, it is necessary to reckon with budget constraints. There are two ways by which you can pay for your expenses: you can increase revenues or borrow money. Governments can also use these two ways: they can increase revenues by raising taxes, or can deepen debt, issuing government bonds. Unlike other economic agents, the government has a third way - can issue money and use them to pay for goods and services that it buys.

The budget deficit is the excess of budget expenditures over budget revenues. If for a certain fiscal year budget revenues exceed expenses, then the amount of the difference there is a budget surplus, or excess.

The national debt is the total amount of debts of the state. The classic definition of public debt refers to government debt, excluding the debt of the region budgets, cities and other administrative-territorial units. But in some definitions, but the debt of the government, state debt includes the debt of the nationalized enterprises, as well as the amount of local budgets debt. Then, perhaps, more appropriate seems the term "national debt" instead of "public debt". Also determine net national debt, which is equal to the difference between total national debt and domestic debt. 
The government balancing the state budget by the fiscal stabilization policy. So, the Ukrainian scientist Yu. Petlenko identifies the following features of the state fiscal policy (Petlenko and Mylovanova, 2017): 1) the most important instrument of fiscal policy is the budget deficit as a result of the state financial activities consequently to its economic and social development; 2) financial activity of the state regarding the regulation of the budget deficit is manifested in interference in the economy, on the one hand through the implementation of the policy of budget revenues formation, on the other hand, as a mechanism to stimulate activities of economic entities; 3) state intervention in the economy affects macroeconomic equilibrium - the aggregate demand and supply, and also aim to reduce the negative impact of economic cycles on the stability of business activity.

At the same time, John Stiglitz explored the fiscal policy through tax burden and the optimal structure of the tax system, which aims to improve the welfare of the population (Stiglitz, 1999).

Discretionary fiscal policy, which aims at effective use of public budget, always solves a difficult alternative: stabilization of the economy or balancing of the state budget. This becomes particularly acute if the fall in production caused by a deficiency of aggregate demand. On the one hand, to stop the decline in production, it is necessary to apply a stimulating fiscal policy. On the other hand, it will increase the budget balance, that is, sends the budget to the deficit.

Budget balancing can be carried out in the following ways:

1. Annually balanced budget.

The annual policy balancing the budget enhances the action of economic cycles, that is pro-cyclical. For example, unemployment is increasing (in the recession) -> incomes decline, therefore $->$ decreases the tax base $->$ reduced budget revenues. In addition, growing budget expenditures (assistance to the unemployed, and the like) -> Have a deficit budget. If in these circumstances balancing the budget to prevent a deficit, $->$ will be necessary to increase taxes and/or reduce costs $->$ to worsen the already depressed state of the economy.

If on the contrary, have full employment and inflation, - $>$ increases the tax base and budget costs are reduced $->$ occurs budget surplus. In these circumstances, balancing the budget will require reducing taxes and/or increasing costs $->$ and this will increase the inflation.

2. Cyclically balanced budget.

Cyclic balancing of the budget involves the simultaneous implementation of counter-cyclical government programs and balancing the budget, but not on an annual basis. During the recession, the government lowers taxes and increases spending, while deliberately aggravating the budget deficit. During ascent, the government acts on the contrary: it increases taxes and reduces spending, while deliberately increase its budget surplus.

But overall for the whole period of the economic cycle observed the budget balancing. However, the main problem is that economic cycles are not uniform in duration and depth. In addition, development stage and decline stage do not always pass for the same duration of time.

3. Functional finance.

Supporters of the functional finance system are seeking a balanced economy. The goal of a balanced budget pales into insignificance.

In their opinion, the state budget is not a matter of stabilization. The main thing is the economy balance. And it does not matter if this achieved by using the budget 
surplus or budget deficit. The government has a large, if not infinite, possibilities to finance the budget deficit.

Based on the concept of functional finance, the current fiscal policy allows the possibility of using an unbalanced budget. First of all it concerns the budget deficit. If the budget deficit is a necessary condition for the stabilization of the economy, on the one hand, the government consciously creating it; on the other, it provides for certain sources of funding.

The choice of rational relation between the individual sources of funding is an acute problem of fiscal policy. It is commonly accepted that the greatest threat to the economy is monetary emission. Its use as a source of funding budget deficits generates uncontrolled inflation, undermines incentives for long-term investment, devalues the savings of households, reproduce the budget deficit.

To limit monetary emission in many countries, the Constitution stipulates the independence of the national issuing banks from the government. Furthermore, the amount of monetary emission is governed by the Parliament.

Painless sources of budget deficit financing do not exist. Therefore, effective can be only a prudent fiscal policy, according to which the state must continually adjust its costs in response to changes in income, and government loans be used only if they have the potential to create sources for their return.

It is essential that the share of the national debt owned by foreigners was moderate. If it is very large, for the country significantly increases the risk of default and are washed out financial resources of the national economy.

The global financial science ambiguously evaluate the effect of budget deficit on socioeconomic processes in society. Therefore, considering the socio-economic consequences of the budget deficit, it is necessary to consider various factors and ways of influence of the deficit on the economy, social sphere and social protection of population taking into account specific situations. Considering these approaches, the consequences can be positive, negative or absent.

What about the positive influence of budget deficit on the economy wrote John M. Keynes. Developing the Keynes theory, neokeynesians argued about the need for a balanced budget in time, i.e. need to replace budget deficits during wars and crises by the active budget during economic upswings. Consequently, the budget deficit was considered an anti-crisis factor. After World War II, Keynesian theory was used in almost all industrialized countries, with the result that the budget deficit became an important fiscal policy instrument, was used during the solution of diverse problems and took an important place in the theory of economic growth and cyclical theories of economic regulation (Mashko, 2010).

Today the vast majority of theorists and practitioners of the world are inclined to think that the budget deficit has a negative impact on the socio-economic processes in society. The budget deficit is a cause of reduced efficiency of the tax system, weakening incentives to work, undermining the confidence of members of society in the future.

Since stabilization policy is reduced to the manipulation of the state budget and changes in the money supply, its implementation directly affects the size of the budget deficit and public debt. The state budget deficit can be financed either through its monetization, or for the account of the loan from the population or from the rest of the world. Because the monetization of public deficit means an increase in the money supply, contributes to the growth of national income, under certain conditions, this can eliminate the budget deficit. After the exhaustion of the possibilities of reducing budget deficit through monetization of the public debt it is growing by the size of the budget 
deficit this year.

With a large public debt expenses on its maintenance that is the primary expenditure of the state budget significantly limit the ability of the government in fulfilling its core functions and in the conduct of stabilization policy.

Payments on the public debt may be the main or even the sole cause of the budget deficit, creating a vicious circle: state budget deficit $\rightarrow$ increase in the national debt $\rightarrow$ increase in debt service costs $\rightarrow$ state budget deficit.

The general state budget deficit reduced by the amount of interest payments on the national debt, called the primary deficit. In countries with large public debt, in the absence of the primary deficit often there is a general deficit of the state budget. This is the situation in Russia in 1999-2000.

The government in its activity is committed to a balanced allocation of costs and revenues. In order to achieve this, you need to have a clearly established system of budget management, which could ensure the efficient use of funds.

The budget deficit is a financial phenomenon, not necessarily related to the category of extraordinary events. In today's world no state, which in certain periods of its history are not experienced with the budget deficit.

In Ukrainian economic science, until recently, prevailed a purely negative view on the budget deficit. It was seen as a very negative feature typical for the developed countries budgets. Extremely negative consequences (financial, economic, social) of huge budget deficits require the implementation of a system of measures on its overcoming, carrying out an active fiscal policy, the use of internationally accepted methods of dealing with the deficit. Striving for balancing budget income and expenses by balancing the state budget today is one of the main tasks for the government.

In most countries of the world, including Ukraine, budget deficits became chronic, which contributes to the deepening of financial instability. They give impetus to inflation and diverts significant amounts of financial resources from the private sector. Inability to control and withdrawal of the question of the budget scarcity constraint are the cause of the deterioration of financial discipline in the country and deepening of the financial irresponsibility of governments (Danylenko, Grytsenko, and Zymovets, 2010).

Below we can see the dynamics of the Ukraine budget deficit for $2008-2016$ years (Table 1):

Table 1. The dynamics of the Ukraine state budget in 2008 - 2016 years

\begin{tabular}{|c|c|c|c|c|c|c|c|c|}
\hline \multirow[b]{2}{*}{ Year } & \multicolumn{2}{|c|}{ Revenue } & \multicolumn{2}{|c|}{ Expenditure } & \multicolumn{2}{|c|}{ Lending } & \multicolumn{2}{|c|}{ Balance } \\
\hline & $\begin{array}{c}\text { mln } \\
\text { UAH }\end{array}$ & \%GDP & $\begin{array}{c}\text { mln } \\
\text { UAH }\end{array}$ & $\%$ GDP & $\begin{array}{c}\text { mln } \\
\text { UAH }\end{array}$ & $\%$ GDP & $\begin{array}{c}\text { mln } \\
\text { UAH }\end{array}$ & $\%$ GDP \\
\hline 2008 & 231686,3 & 24.44 & 241454,5 & 25.47 & 2732,5 & 0.29 & $-12500,7$ & -1.32 \\
\hline 2009 & 209700,3 & 22.96 & 242437,2 & 26.54 & 2780,3 & 0.30 & $-35517,2$ & -3.89 \\
\hline 2010 & 240615,2 & 22.23 & 303588,7 & 28.04 & 1292,0 & 0.12 & $-64265,5$ & -5.94 \\
\hline 2011 & 314616,9 & 23.90 & 333459,5 & 25.33 & 4715,0 & 0.36 & $-23557,6$ & -1.79 \\
\hline 2012 & 346054,0 & 24.56 & 395681,5 & 28.08 & 3817,7 & 0.27 & $-53445,2$ & -3.79 \\
\hline 2013 & 339180,3 & 23.31 & 403403,2 & 27.73 & 484,7 & 0.03 & $-64707,6$ & -4.45 \\
\hline 2014 & 357084,2 & 22.79 & 430217,8 & 27.46 & 4919,3 & 0.31 & $-78052,8$ & -4.98 \\
\hline 2015 & 534694,8 & 27.01 & 576911,4 & 29.14 & 2950,9 & 0.15 & $-45167,5$ & -2.28 \\
\hline 2016 & 616274,8 & 25.86 & 684743,4 & 28.73 & 1661,6 & 0.07 & $-70130,2$ & -2.94 \\
\hline
\end{tabular}

Source: Implementation of the state budget of Ukraine, 2017

The rapid elimination of the budget deficit, not accompanied by real steps towards stabilization of the economy, will only complicate the already difficult financial 
situation in the country, creates unnecessary obstacles in the way of decent exit from the crisis.

The reason of financial policy inefficiency in Ukraine during the whole period of independence is the lack of clearly defined and articulated goals of social development, goals and strategic objectives for the long term, which led to uncertainty of role of the state, especially in relation to the content and instruments of this policy (Balastryk, 2010). An important step in the struggle to reduce the budget deficit in Ukraine is to develop an optimal model of fiscal rules, which would meet the criteria of clarity of definition, transparency, adequacy, consistency, simplicity, flexibility, mandatory execution, and support from other areas of economic policy.

According to fiscal rules each year in the process of drafting, review, approval and execution of the budget, it is advisable to carry out complex tactical actions associated with balancing the budget, reducing the budget deficit.

Deficit financing of national economy can be justified only under the condition that the rate of GDP growth will outpace the growth in state and local budgets and the costs of servicing the public debt. In the world practice one of the most important methods of dealing with the deficit is the fiscal rules have been widely used in connection with the trend towards decentralization of the budget system in order to avoid macroeconomic and financial instability. Fiscal rules depends on the needs of the budget system in resources. They are severely restricted at all levels of the budget process and institutional characteristics of the country. They acquire the shape of legislative norms, budget process procedures and marginal indicators (Demianyshyn, 2009): a) The balanced budget rules. Among the rules of a balanced budget the central place is occupied by the "golden rule" of public finance, which implies a balanced budget of revenues and expenditures, i.e. the budget deficit may not exceed the total volume of state investments (Japan, Germany, USA), the cyclical budget balance (Denmark, Netherlands, Switzerland) and setting a limit on the size ratio of budget deficit to GDP of the country (European Union countries); b) Regulations on state borrowing. Among the rules regarding restrictions and prohibitions of government borrowing are the following: the prohibition of internal state borrowings (used in countries with underdeveloped financial markets, for example, in Indonesia), the prohibition of government borrowing from the Central Bank (the European Union, Japan, USA) and size limits of government borrowing to last year's volumes of the countries budget deficit (Brazil, Egypt, Morocco); c) Debt and reserve rules. Debt rules require the establishment of limits on the size of the ratio of public debt to GDP, and the reserve - associated with the formation of special funds to prevent financial crises, when the need arises to support the social benefits of a reduction in revenue of the state budget.

If fiscal policy is focused on extending the state sector of the national economy, it should increase fiscal spending and taxes, creating a stimulant effect. When fiscal policy is aimed at supporting the private sector, it should reduce taxes and limit budget spending, which is fast enough to reduce inflation.

In addition to fiscal rules in the preparation and execution of the state budget, it is advisable to carry out complex tactical actions related to the reduction of budget deficits (Kolisnyk, 2011): a) improvement of legal support of the budget process, make the necessary changes in the laws and legal acts which would ensure the balancing of the state budget at all stages of the budget process; b) improvement of the transfer policy and improving the effectiveness of transfer payments, in particular the reduction of payments to unproductive branches of national economy; c) the rejection of the deficit 
financing concept (a situation in which expenses exceed planned revenues funded from additional received income and attracted budgetary sources); d) counteraction to "dirty" money laundering, better state program support of the national economy deshadowing and strengthening of managers responsibility at all levels of government for misuse of budgetary funds; e) the introduction of strict regime of budgetary funds economy, in particular reducing the cost of public administration, elimination of unjustified and ineffective economic and social benefits and the like.

The other important stabilization area is monetary sphere. Monetary regulation of economy is carried out by using the so-called transmission mechanism. For the first time this concept was introduced by John M. Keynes. Scientist called so the system of variables through which the money supply affects economic activity (Keynes, 1999). Today, there are many points of view on the definition of this concept. In my opinion, most fully the economic essence of the monetary transmission definition displays V. Stelmakh, according to whom "the transmission mechanism is the relationship associated with the transmission of changes in the use of monetary policy instruments on macroeconomic variables through a complex chain of intermediate variables" (Stelmakh, 2009).

In the process of transmission mechanism implementation the effect of the Central Bank activity affects the real economy with a certain time lag. First, the effect of using monetary policy is reflected directly in the money supply that causes changes in the performance of the financial sector, such as interest rates, exchange rate, volumes of deposits and loans. These changes in turn affect the adoption of economic actors in decisions about production, consumption, savings, and investments. For example, high interest rates have a negative impact on the propensity to investment, and taking into account the multiplier, on the economy as a whole (Bazylevych, Bazylevych, and Balastryk, 2007). Ultimately, this leads to a change in the gross domestic product.

Thus, schematically, the stages of the transmission mechanism action can be represented as follows: The change in the money supply $\rightarrow$ Change in the financial sector (interest rates, exchange rates, volumes of loans and deposits and the like) $\rightarrow$ Changes in the real sector (investment, consumption, net exports, etc.) $\rightarrow$ Change of GDP

The impact of monetary policy instruments on the main economic indicators of the country is carried out through a chain of intermediate variables, or in other words, the channels of the transmission mechanism. The formation of various channels depends on the Central Bank transmission mechanism model. The Central Bank takes into account national peculiarities of the economy, the main of which are the scale of the economy, its openness, level of development, tools and goals of monetary policy (Mishchenko, Petryk, Somyk, Lysenko, and others, 2008).

Today the transmission mechanism model of Ukraine monetary policy is at the design stage. In the structure of monetary transmission mechanism in Ukraine today there are such channels as monetary, channel of interest rates, channel of assets prices, credit channel and channel of economic agents' expectations. Let us consider each of them separately.

Monetary channel, as considered in scientific literature, is the first channel of the transmission mechanism, which really began to be used in practice. Its action is characterized by direct effects of money supply on the monetary market and the price level in economy.

Monetary channel influences due to the fact that the optimum growth of the money base and the money supply to balance the structure of the money market plays a 
crucial role in the formation of inflation, prices and value of assets. The criterion of the monetary channel effectiveness is the observation of the money base growth, as well as the proportions of money supply growth.

Today in Ukraine, this channel is used quite actively because the operational target of monetary policy is the money base indicator. After the introduction of inflation targeting, the role of this channel will decrease, since the operational target of monetary policy should be the interest rate (Mishchenko, Somyk, and Lysenko, 2010).

Interest channel is the main channel of transmission mechanism. Its effect is that the change in the money supply affects the interest rates. The latter leads to a change in consumption, savings and investment. The ultimate impact indicators is the GDP, inflation or other strategic indicators.

The scheme of functioning of the monetary transmission interest rate channel can be represented as follows: The change in the money supply $\rightarrow$ Changes in interest rates $\rightarrow$ Changes in volume of consumption, savings, investments $\rightarrow$ Change of GDP

Within this channel, there are two separate channels: substitution and income. The effect of the substitution channel is that the change in interest rates affects the ability of subjects to meet their needs, in particular, puts before a choice: to fulfill own needs now, or save and implement them in the future. That is, lowering the interest rate increases current consumption, including the expense of the loans. The latter stimulates the growth of aggregate demand and production volumes. The increase in interest rates leads to an increase in savings and decrease in consumption, which leads to a decrease in demand for loans. As a consequence will be a fall in aggregate demand and decline in production (Arzhevitin, 2009).

The effect of channel of income is based on the fact that the change in interest rates leads to a redistribution of income between creditors and borrowers. For example, higher interest rates contributes to the redistribution of income in favor of the lenders. Because creditors are less inclined to spend savings than borrowers, the result will be a decrease in aggregate spending, which will restrain the growth of aggregate demand, particularly investment. Ultimately will be a decrease in production volumes (Slipchenko, 2011).

Enhancing of the effectiveness and efficiency of the interest rate channel functioning requires the following steps: development of a clear strategy for monetary policy; development of indicative interest rate and money market indicators; improvement of operating system of the banks liquidity regulation; development of the secondary securities market.

Channel of assets prices operates through changes in relative prices of financial and real assets. The Central Bank with tools of monetary regulation changes the volume of the money supply, which affects interest rates. The changes of the past affect the price of assets, such as securities, foreign currencies, real estate and the like. This is because, for example, in the case of lower interest rates the yield of money as an asset reducing. Economic actors starts to look for alternative objects of investment capital, the prices of which, due to increase in demand, grow.

Some scientists allocate as a composite channel of assets prices channel in Ukraine monetary policy the channel of the exchange rate. The latter is a key element of monetary regulation in an open economy. The action of the exchange rate channel is that in case of domestic interest rates reducing, which is a consequence of the increase in money supply, the demand for the national currency decreases, which leads to a decrease of the national currency, and consequently, to growth of net export and aggregate demand (Andrushchak and Khar, 2011): 
The change in the money supply $\rightarrow$ Changes in interest rates $\rightarrow$ Change of the national currency exchange rate $\rightarrow$ Changes in net export and investment $\rightarrow$ Change of GDP

The effect of the influence of national currency exchange rate on the total expenditures can be decomposed into the effect of changes in relative prices and balance sheet effect.

The effect of changes in relative prices turns out in changes in the demand for domestic goods and services, which during the reduction in the national currency exchange rate become cheaper on the world market. This leads to an increase in aggregate demand through higher net export, which is an integral part of the gross domestic product of the country.

Balance sheet effect of change in national currency exchange rate is associated with the presence of liabilities in foreign currency in economic entities balance. If these liabilities are not fully covered by assets in a foreign currency, the rates growth may lead to changes of equity and the cost of servicing foreign currency obligations.

The main directions of the exchange rate channel efficiency increase should be: increasing the liquidity of the foreign currencies market; clear permanent conditions of the Central Bank release on the currency market; reducing the level of the economy dollarization; improvement of currency risks hedging mechanisms.

Credit channel. The impact of the Central Bank's monetary policy on the availability of credit resources reflects the credit channel. It is based on the assumption that the Central Bank affects by instruments of monetary regulation on the change in supply of credit resources by changing the amount of the banking system free reserves:

Tools of monetary policy $\rightarrow$ Change in free reserves $\rightarrow$ Change of the credit volume $\rightarrow$ Changes in volume of consumption, savings, investment $\rightarrow$ Change of GDP

The main directions of improving the effectiveness of the credit channel should provide: improvement of credit and investment climate; the financial recovery of the banking system and its stability enhancing; development of mechanisms for the provision by Central Bank refinancing loans for investment projects financing (only for investment banks); improvement of credit conditions and strengthening of the creditors' rights protection mechanisms.

Channel of expectations characterizes the impact of changes in monetary policy on the economic agents expectations regarding future prices and macroeconomic situation and, accordingly, on their decision on consumption, savings and investment.

It is worth to notice that the instruments of monetary regulation are reflected directly in short-term rates on the money market. The reaction of long-term rates on the Central Bank operations depends on market expectations and confidence of market participants in targets of monetary policy. If monetary policy is consistent with the goals, and the macroeconomic situation is stable, the effect of the expectation channel will be negligible. When there is uncertainty in economic conditions due to low confidence in the governmental and monetary policy, generated pessimistic expectations that block incentives for economic growth.

The negative expectations of economic agents may be the cause of disruption in the transmission mechanism and reducing of the monetary regulation instruments impact that could cause significant deviation of actual values from the targets of monetary policy.

The presence of economic agents' negative expectations could be shown by such indicators as growth in money velocity, the share of loans and deposits issued in foreign currency increasing, a significant share of cash in the money supply structure and other. 
It should be noted that in addition to the channels, which are characteristic for the Ukraine's economy, in the framework of the monetary transmission mechanism allocate such channels as liquidity channel, channel of changes in equity, Tobin's $q$, which relate to the channel of asset prices, etc.

Liquidity channel defines the relationship between the financial assets owned by households, and their (households') expenditures on the durable goods (cars, home appliances, real estate). In the basis of functioning of this channel is the desire of households to distribute the proceeds between the various assets in such way as to be able at any time to avoid financial difficulties. In this regard, households tries to store part of the cash revenues in the form of cash or highly liquid income-bearing financial assets. If in the household's assets structure investments in financial assets have a significant place compared to the debts of this subject, we can conclude that the probability of financial distress for this subject is low. Such households will be able to buy consumer durable goods.

Based on these assumptions, the effect of the liquidity channel can be characterized as follows: money supply growth leads to higher stock prices, resulting in a lower likelihood of financial difficulties, and households begin to increase their spending on durable goods. As a result, the aggregate demand and, consequently, production volumes will increase.

The influence of the channel of changes in equity on the real economy is as follows: increase in money supply leads to an increase in the value of firms' equity. The consequence of this, given that equity can be used as collateral, is the increasing of its cost. This has a direct impact on the creditworthiness of borrowers, because when it grows commercial banks begin to expand lending, which leads to production volumes increasing.

Thus, since the equity of the borrower indicates the stability of its activity and can be a guarantee of fulfillment of obligations under loan agreements, changes in bank clients equity influences the banks' decisions regarding the expansion or narrowing of their customers crediting. Consequently, this will affect the consumption and investment and will have an impact on production (Arzhevitin, 2009).

Some scientists identify this channel as a broad channel of lending and call it balance channel. Then, respectively, the influence of Central Bank on money supply through a change in reserves is called the narrow channel of lending.

The basis of the Tobin's $q$ channel action is the relationship between the stocks' price and the investment costs of the company. The Tobin's q is defined as the ratio of a firm market value and of replacement cost of its capital. The first one is the price at which the firm can be sold on the market, while replacement cost is the value of the firm in case if all its capital (machines, equipment, buildings and the like) were replaced with a new equipment at prices that have formed at the current moment on the market. If Tobin's q is high, this means that the cost of the firm's capital equipment is lesser compared to the market value of the company.

The effects of monetary impulses into the real sector through this channel are as follows: the increase in money supply raises the prices of securities that leads to an increase in the market value of firms compared to the replacement value of its capital. In this case, firms can issue new shares and sell them in the market at high prices. Additional financial resources will be directed to investment expansion, the purchase of new machinery and equipment. Thus, under conditions of constant prices for capital equipment growth in the Tobin's q will increase the level of investment spending. The consequence would be an increase in aggregate demand and production. 
The strategic goals of economic development and successful application of the entire set of anti-crisis measures crucially depend on the effectiveness of marketoriented instruments of the Central Bank's monetary impact on the economy, a standard set of which is represented by the minimum reserve requirements, discount policy and open market operations. However, there is a problem of achieving maximum effect in a relatively short time (Dzyublyk, 2012).

In conditions of low economic growth rates, inflation and devaluation of the national currency it is extremely important to find ways to overcome the negative effects of the aforementioned processes and phenomena. Given the uncertainty factor, the influence of Central Bank on the country's economy is quite powerful. The main direction of a monetary policy improvement is to change its regime on more effective. The research urgency is caused also by the desire of the National Bank of Ukraine (NBU) to move in the near future to full-fledged inflation targeting. In the "Main principles of monetary policy for 2015", it is noted that strategic objective of the NBU is to achieve and maintain in the medium term low and stable inflation $(5 \%$ per year with a tolerance of $\pm 1 \%$ ) and a gradual transition to inflation targeting. Thus, one of the research problems is stated as follows: is the inflation targeting regime the best choice for Ukraine? The current paper aims to demonstrate differences in implementation of basic monetary regimes and to prove that the inflation targeting regime will be the most effective for Ukraine.

In most cases, Central banks choose one of three basic nominal indicators characterizing the results of its activity: the existing amount of money in circulation, the value of the exchange rate or the inflation rate. Providing the stable dynamics of these variables on the read level for a certain period of time is called its targeting (Koncewicz, 2012).

We can consider three basic choices of monetary regime. The first is the regime of monetary targeting. It is based on the belief that the change in the money supply entails a corresponding change in the rate of inflation. In order for this regime to be effective, a necessary condition is the existence in the economy a stable connection between the change in the money supply and inflation.

The second monetary regime based on the exchange rate targeting. It suggests that the Central Bank as the intermediate target of monetary policy sets the nominal exchange rate and tries to provide stability against the currencies of the so-called countries of the anchor due to interest rate changes and direct foreign exchange intervention.

The third monetary regime is based on inflation targeting. Also some Central banks are adopting a strategy without an explicit nominal anchor, which consists in establishing and achieving several goals simultaneously (Gnativ, 2009).

The essence of monetary targeting is that the Central Bank, on the basis of the inflation target, estimate of potential output growth and the dynamics of money velocity within the quantitative equation of exchange ( $\mathrm{MV}=\mathrm{PY}$ ) determines the target rate of monetary aggregates growth and announces it to the public.

For the implementation of monetary targeting in the country, you need to meet an important condition: the demand for money within the country should be stable. This means that the velocity of money has to be on the same level for a certain horizon targeting. This condition is quite difficult task for the Central Bank. The reason is that the demand for money depends essentially on the changes occurring in the socioeconomic relations, the stability of international financial markets, and the like. Given this, the effectiveness of this regime is low in countries with economies in transition. 
During 1970-2000 the monetary targeting was tried in many countries such as UK, Greece, Albania, Georgia, China, etc. Most of them were forced to abandon this regime due to low efficiency of monetary aggregates influence on the ultimate goal price stability.

Examples of effective targeting of the money supply are Germany and Switzerland. Indicators of monetary targets in these countries were achieved only by $50 \%$, however, inflation has been kept at an average level that does not exceed $3 \%$. The effectiveness of this regime in Germany and Switzerland was based on the confidence in the monetary authorities (Radionova, 2009).

Ukrainian scientist T. Slipchenko noted that the main advantages of monetary targeting as a monetary regime is "sovereignty" - the Central Bank chooses the inflation target, and has the ability to adjust policy depending on internal changes in the volume of production and a close relationship with the instruments of monetary policy, that is, a high level of control by the Central Bank, since monetary aggregates are measured quickly enough, and, accordingly, reports on the implementation of monetary targets communicated to the public with relatively short time lags up to several weeks (Slipchenko, 2010).

As you can see, the advantages of this regime include a high level of coordination of monetary and overall macroeconomic policy, the ability to rapid reaction by the Central Bank and the stability of expectations associated with full awareness.

The disadvantages include the impossibility of control over the money supply in case of high share of cash, insolvency in case of significant fluctuations in the demand for money, the ambiguity of the relationships between changes in the money supply and its actual performance in time intervals (Prushkovskaya, 2010).

Not less than 50 economies of the world continue to rigidly fix the courses of their currency units relative to third currencies. These include, for example, Hong Kong, Malta, Latvia, Lithuania, Estonia, etc. Selection of the regime of the exchange rate targeting is an effective tool to control inflation. The effectiveness of this regime directly depends on such factors as the degree of openness of the economy measured by share of imports in consumption, the volume of foreign exchange reserves and so on (Papaika, 2010).

The disadvantages of this regime are the dependence of monetary policy on external economic factors, the possibility of an inflow of short-term speculative capital and the risk of destabilization of the financial system in the global currency crises.

As shows the analysis of the experience of individual countries, the policy of the exchange rate targeting may have different consequences. Thus, the positive results were achieved in Bulgaria, Latvia, Tunisia, Argentina. A classic example of a country that had a bad experience is Brazil, where the application of the regime of the exchange rate targeting led to hyperinflation.

In 1990 the Reserve Bank of New Zealand was the first to use inflation targeting regime. Currently, such policy is carried out in at least 26 countries, including economically developed countries (Australia, Sweden, Canada, UK), developing countries (Brazil, Chile, Mexico), and countries with emerging market economies (Poland, Czech Republic, Slovenia, Hungary). The last introduced the inflation targeting regime during the transition period, with the result that has reached the low level of inflation and sustainable economic growth, and also raised public confidence in the monetary authorities.

The concept of "inflation targeting" is defined as the monetary strategy that involves public announcement of the inflation temps by Central Bank that must be 
achieved within a certain period, and provides increased transparency and accountability of the monetary regulation bodies.

An important condition for the transition to the inflation targeting regime is a presence of Central Bank's clear vision of how monetary policy affects the real economy. This makes it possible to determine which instruments are appropriate to use in a given situation, time lag of the measures of the Central Bank impact on macroeconomic indicators and how they will be effective. In the developing countries the influence of monetary policy on the economy is characterized by greater uncertainty due to permanent institutional and structural changes.

The technology of conducting monetary policy under inflation targeting is based on two main principles. The first is a forecast of how the inflation process will develop for the assumption that monetary policy will not change. The second is a prediction as to what will be the future inflation and other macroeconomic indicators in the case of current changes in monetary policy.

So, if the inflation forecast exceeds the inflation target, the Central Bank needs to raise interest rates, and vice versa, if the inflation forecast is below the inflation target, the Central Bank should reduce the interest rate.

It should be noted that the effects of monetary policy occur with a time lag, so the medium-term forecast of macroeconomic development, in particular inflation, has a sufficient importance. Since the applying of inflation targeting regime the deviation of the predicted values of inflation from the target acts as an intermediate goal, so the quality of the forecast becomes the key element of the effectiveness of monetary policy (Gritsenko, 2008). Thus, the effective system of analysis and forecasting is one of the most important preconditions for a successful transition of Central banks from the exchange rate targeting regime to the inflation targeting regime.

Central banks applying inflation targeting, target out also inflation expectations, which serve as a connecting thread between operating targets and the ultimate goal of monetary policy. Not only the officially proclaimed inflation target is affected on the expectations of economic agents, but also its forecasts, which are specified by the Central Bank in periodic public reports.

The process of forecasting by the monetary authorities is a "black box" for the public and associated with the use of a number of complex macroeconomic regimes. If economic agents trust the Central Bank, even unexpected external and internal shocks, which were not considered by the Central Bank in the forecasting process, may be impaired by the influence of optimistic inflation expectations. That is, the expectations of economic agents are influenced both by the actual change of the direction of monetary policy, and just announcements about upcoming intentions of the Central Bank.

Inflation targeting is implemented through active and passive approaches. Passive approach includes the following monetary policy tools: a narrow corridor of the interest rates in the interbank market, the conduct of irregular transactions in the open market, the use of reserve requirements to regulate liquidity. Active approach, in turn, provides for a wide interest rate corridor, the lack of regular transactions in the open market and minimal use of reserve requirements.

International experience of inflation targeting regime confirms its effectiveness, since none of the countries that have adopted this strategy, abandoned it. In these countries, today the macroeconomic situation is characterized by steady economic growth, less vulnerability to external shocks, low and stable inflation. 
Application practice shows the existence of subtypes of this regime, as different countries use inflation targeting that was developed according to their system characteristics. Such subtypes include: a) full-fledged inflation targeting - full transparency lighting inflation target, strict adherence to the selected target without corrective measures from the Central banks. First used in New Zealand, later on it spread among developing countries, particularly in Brazil, Colombia, Hungary, Mexico and Poland; b) disguised inflation targeting - allows changes in the level of inflation. In this subtype of the regime there is a certain opacity. Used by the European Central Bank and by the Federal reserve system of the United States; c) experimental inflation targeting - means the broad inflation tasks proclamation in conditions of low public confidence in the Central Bank.

The advantages of inflation targeting are: the ease of evaluating the effectiveness of monetary policy, a flexible exchange rate policy and creation of conditions for balanced development of all sectors of the economy, slowed because of the negative impact of inflation.

According to domestic economist V. Gordienko, the significant benefits in the monetary policy regime of inflation targeting include: 1) formation of inflation expectations at a low level; 2) in most cases allows to reduce inflation in the short term; 3) helps to strengthen the actual Central Bank independence and credibility; 4) allows to overcome internal and external shocks; 5) resolves contradictions associated with the objectives of monetary policy; 6) reduces the likelihood of crises; 7) creates positive conditions for the development of the economy as a whole (Gordienko, 2012).

The disadvantages of this regime you need to include are the impact of factors that are not controlled by the Central Bank (e.g., the status of the financial sector) on the inflation dynamics, as well as limiting opportunities for stimulating economic growth and reducing unemployment with monetary policy instruments.

Based on the experience of other countries, the main direction of improvement of the monetary policy of Ukraine is determined as a phased transition from the regime of targeting the exchange rate (which was defined as a financial priority of the monetary policy of Ukraine in 1997 (Bazylevych, Bazylevych, and Balastryk, 2007)) to the regime of inflation targeting.

During the first stage, you need to reduce utilization of foreign exchange interventions that will make the exchange rate more flexible and to increase the influence of interest rate policy, which should become the main tool of the NBU. It is also important to implement a number of measures aimed at development of the stock market of Ukraine.

The purpose of the second stage is the transition to full inflation targeting by further liberalization of operations with capital movement. The main results of the second stage should be the transparency and efficiency of the impact of interest rate policy and a flexible exchange rate.

The criteria for the formation of the most favorable environment for the transition to the inflation targeting in the country are: the Central Bank independence, transparency and informational openness of the NBU, Central Bank credibility, a qualitative inflation forecast, high level of training of analysts and a robust statistical base, a developed financial market, free pricing, low level of dollarization of the economy, coordination of instruments of monetary and fiscal policy (Kalinovskyi, 2017).

So, the possible positive aspects of the implementation of inflation targeting in Ukraine include: 1) increasing trust of the population, primarily in the National Bank of 
Ukraine and the Government, which is one of the factors in the formation of inflation expectations; 2) ensuring stable economic development of Ukraine in the long term; 3 ) increasing of foreign investment (which will affect the development of financialcredit sector and the economy as a whole); 4) lower prices for imported goods; 5) increasing of transparency and efficiency of functioning of the government securities market; 6) creation of mechanisms to counter external shocks and manage cash flow in all sectors of economy; 7) reducing the likelihood of crises.

However, according to Vishnevska, the implementation of the inflation targeting regime in Ukraine in the absence of basic preconditions was a necessary step, but, as practice shows, untimely, and the proof is the inability of the NBU in 2014 to ensure price stability in conditions of macroeconomic instability (Vishnevska, 2015).

The inflation targeting regime was implemented in unfavorable for Ukraine's economy conditions, in particular with inflation almost at $24.9 \%$ in 2014 , the devaluation of hryvnia by almost $310 \%$ (from 8.3 UAH/USD in 2013 to around 34,0 UAH/USD in February 2015) and the fall of GDP by $15.2 \%$ in 2014. The influence of the external environment will further increase the dependence of inflation targeting on the budget needs (Kornev, 2015).

\section{CONCLUSIONS AND RECOMMENDATIONS}

\section{Conclusions}

Chronic state budget deficit is a significant threat to the economy, because it delays the financial resources of the state for the servicing and repayment of public debt. On the other hand, it requires a fixed financing of a certain amount of government spending to maintain the priority sectors of the economy and the target level of employment, even if it leads to the budget deficit deepening. The search for optimal strategies for balancing the budget under these conditions is the basis for further research.

A promising direction for further research in the area of improving the functioning of the transmission mechanism in Ukraine is the rationale for the development of secondary securities market, which will lead to not only revive the monetary and financial markets, but also to the more significant influence of the Central Bank on the real sector of economy, as well as in-depth analysis of the inflation targeting regime, directly connected with the transmission mechanism of monetary policy, that may lead to more effective impact of the Central Bank on the economy of Ukraine.

The impact of budgetary processes on the economic situation in the country is a fundamental milestone in the definition and conduct of macroeconomic stabilization policy. The classic lines of reducing the budget deficit is to increase revenue and decrease expenditure, internal and external borrowing. However, you should consider the positive and negative aspects of each of them and to produce in each of these tools effective measures to stimulate the reduction of the budget deficit.

The implementation of monetary policy occurs via the transmission mechanism. Under this concept understand the relationships associated with the transmission of changes in the use of monetary policy instruments on macroeconomic variables through a complex chain of intermediate variables. The latter are also known as channels. Each of them conveys the monetary impulse from the specific tools of the Central Bank to the real sector of economy. The effectiveness of these channels is determined by the result of influence on the final targets, in particular on gross output. 
Analyzing the considered channels of the transmission mechanism of monetary regulation, we can conclude that for Ukraine due to the lack of a developed stock market is characterized a limited number of channels: monetary, channel of interest rates, channel of assets prices, credit channel and channel of economic agents' expectations. In addition to these, there are also liquidity channel, channel of changes in equity, Tobin's q and others.

Today in Ukraine the transmission mechanism of monetary policy is not effective enough, as evidenced by a weak relationship between monetary measures of Central Bank and the dynamics of financial market and real sector development. The cause is because until recently in monetary policy of Ukraine were used monetary aggregates and exchange rate targeting regimes. In conditions of post-crisis recovery, the implementation of the basic principles of the transmission mechanism of monetary policy occurred against the background of macroeconomic instability and monetary strain associated with the imperfection of the institutional framework, methods and tools of monetary policy implementing, as well as of the main approaches in operations of Central Bank.

One of the main preconditions for the effective functioning of the economy is ensuring of a stable and low inflation. The achievement of the inflation target is possible primarily due to the choice of the optimal Central Bank monetary policy. Given the socio-economic realities of Ukraine, the most expedient is the implementation of the inflation targeting regime.

\section{Recommendations}

The fundamental measures to improve the balancing of the Ukraine state budget include the following: improvement of legal support of the budget process, the use of advanced technologies, budget planning and management, improving transfer policy and improving the effectiveness of transfer payments, finding the reserves to increase the revenue of the state budget, the rejection of the deficit financing concept, counteraction to the "dirty" money laundering, the introduction of strict regime of budgetary funds economy and the like.

Inflation targeting should be viewed as a monetary system device, which is characterized by a public proclamation of official quantitative inflation target in the medium term and a clear understanding and confidence that low and stable inflation is the primary goal of monetary policy in the long run. In addition, an important condition for the implementation of this monetary regime is understanding that it will stimulate positive changes concerning the implementation of monetary policy, strengthening the effectiveness of the use of its main tools to increase the independence of the Central Bank in terms of accountability and transparency and will contribute to the development of the system analysis and forecasting of the inflation target in the country.

There are the following ways to improve monetary control in conditions of implementation of the inflation targeting regime: enhancing the role of interest rates in managing inflation through adherence to the basic rules of interest policy; strengthening the capacity of the NBU to develop its own forecasts of macroeconomic indicators, which will be the basis for making monetary decisions and will enhance the independence of the regulator; improving the efficiency of the process of making monetary decisions and improving communication policy with the aim of restoring confidence in the regulator actions; a better coordination of monetary and fiscal policy to achieve the inflation target and keeping it at low levels for a long time. 


\section{REFERENCES}

Andrushchak, Ye.M. \& Khar, V.S. (2011). The transmission mechanism of monetary policy in Ukraine. Naukovyi visnyk NLTU Ukrainy, 21(6), 106-113.

Arzhevitin, S.M. (2009). Channels of monetary transmission. Finansy, oblik i audyt, 13, 7-14.

Balastryk, L.O. (2010). Improvement of methods of strategic priorities implementation in the budget policy of the state. Ekonomika ta pidpryiemnytstvo, 24, 20-29.

Bazylevych, V.D., Bazylevych, K.S. and Balastryk, L.O. (2007). Macroeconomics. Kyiv: Znannia.

Danylenko, A.I., Grytsenko, A.A. and Zymovets, V.V. (2010). Fiscal and monetary policy in Ukraine: problems and ways to strengthen the interconnection. Kyiv: Natsionalna akademiia nauk Ukrainy.

Demianyshyn, V. (2009). Budget deficit and its impact on the crisis situation in Ukraine. Visnyk Ternopilskoho derzhavnoho ekonomichnoho universytetu, 5, 120123.

Dzyublyk, A.V. (2012). Prospects of optimization of the transmission mechanisms of monetary policy in the period of crisis in the financial markets. Finansy, oblik $i$ audyt, 19, 55-64.

Gnativ, A.A. (2009). Inflation targeting as an optimal monetary policy regime in Ukraine. Rehionalna ekonomika, 2, 119-125.

Gordienko, V.P. (2012). Inflation targeting as an effective method of ensuring price stability. Finance and credit activities: the theory and practice problems, 1(2), 1521.

Gritsenko, A.A. (2008). The institution of inflation targeting: international experience and prospects of introduction in Ukraine. Kyiv: Institute of economics and forecasting of NAS of Ukraine.

Kalinovskyi, R.O. (2017). The rationale for the application of the inflation targeting regime in Ukraine. Baltic Journal of Economic Studies, 3(1_January), 52-57.

Keynes, J.M. (1999). The general theory of employment, interest and money. Moskow: Gelios ARV.

Kolisnyk, O. (2011). Management of budget deficit. Svit finansiv, 3-4, 102-110.

Koncewicz, K.S. (2012). The analysis of regimes of monetary policy in various countries of the world. KROK, 1, 214-216.

Kornev, I.V. (2015). The improving of the monetary policy effectiveness and instruments of its realization in Ukraine. Scientific notes of National University Ostrog Academy, 28, 125-129.

Mashko, A.I. (2010). Management of the state budget deficit. Visnyk Khmelnytskoho natsionalnoho universytetu. Ekonomichni nauky, 5, 152-158.

Mishchenko, I.V., Petryk, A.I., Somyk, A.V., Lysenko, G.S. \& others (2008). The monetary transmission mechanism in Ukraine: analytical materials. Kyiv: Tsentr naukovykh doslidzhen Natsionalnoho banku Ukrainy.

Mishchenko, V.I., Somyk, A.V. and Lysenko, G.S. (2010). Peculiarities of action of the transmission mechanism of monetary policy in conditions of crisis. Kyiv: Tsentr naukovykh doslidzhen Natsionalnoho banku Ukrainy.

Papaika, A.A. (2010). World experience of anti-inflationary policy of the state: recommendations for Ukraine. Economics industry, 2, 3-8.

Petlenko, Yu. \& Mylovanova, Ye. (2017). Theoretical and methodological aspects of fiscal policy of the state. Visnyk Kyivskoho natsionalnoho universytetu imeni Tarasa Shevchenka. Ekonomika, 1(190), 28-35. 
Prushkovskaya, E.V. (2010). Targeting as an aspect of monetary policy in conditions of globalization. Ekonomika ta pidpryiemnytstvo, 3, 141-146.

Radionova, I.F. (2009). Macroeconomics-2. Kyiv: KNEU.

Slipchenko, T.A. (2010). Theoretical analysis of monetary regimes and selection criteria for Ukraine. Naukovyi visnyk NLTU Ukrainy, 20, 232-238.

Slipchenko, T.O. (2011). Directions of monetary transmission optimization under conditions of transitive economy. Naukovyi visnyk NLTU Ukrainy, 21(18), 250255.

Stelmakh, V.S. (2009). Monetary policy of the National Bank of Ukraine: modern condition and prospects. Kyiv: Tsentr naukovykh doslidzhen Natsionalnoho banku Ukrainy.

Stiglitz, J. (1999). Economics of the public sector [LBook version]. Retrieved from www.twirpx.com

Vishnevska, V.S. (2015). Economic mechanism of inflation targeting in Ukraine. Lviv: NUL.

Implementation of the state budget of Ukraine. (2017, September 18). Retrieved from http://index.minfin.com.ua/budget/ 